\title{
PEMODELAN PEMILIHAN HASIL PERTANIAN DENGAN METODE WEIGHTED PRODUCT
}

\author{
Evy Poerbaningtyas ${ }^{1}$, Diah Arifah ${ }^{2}$ \\ ${ }^{1}$ Teknik Informatika, STIKI Malang \\ Email: evip@stiki.ac.id \\ 2Teknik Informatika, STIKI Malang \\ Email: diah@stiki.ac.id
}

\begin{abstract}
Abstrak: Dalam era sekarang teknologi komunikasi serta sistem informasi merupakan suatu keharusan yang harus dipelajari dan diimplementasikan. Teknologi informasi dan komunikasi ini sangat penting untuk meningkatkan kualitas sumber daya pangan dan layanan masyarakat. Hubungan yang terjalin antara petani dengan para tengkulak/distributor, merupakan hubungan yang simbiosis Mutualisme. Kedua belah pihak saling membutuhkan. Petani membutuhkan Tengkulak/distributor untuk membeli hasil panennya, sedangkan Tengkulak/distributor membutuhkan hasil panen petani untuk disalurkan kembali ke pengecer atau penjual dipasar-pasar lokal atau diluar daerah. Keadaan yang ada sekarang, petani/tengkulak tidak memiliki media komunikasi yang memadai selain telpon. Dengan keterbatasan media komunikasi telpon tersebut para petani kurang bisa mempromosikan hasil pertaniannya, sedang tengkulak/distributor juga tidak dapat mengetahui di daerah mana saja hasil pertanian dihasilkan. Pada penelitian ini memberikan solusi membangun media komunikasi antara petani dengan tengkulak/distributor berbasis webgis, dimana dalam penelitian ini petani dapat menginfomasikan hasil pertaniannya melalui website tersebut secara uptode, sedangkah para tengkulak/distributor dapat mencari informasi hasil pertanian yang sesuai dengan kebutuhannya. Pada penelitian ini media website dibangun dengan metode WEIGHTED PRODUCT, dimana website dapat memberikan hasil yang lebih baik/optimal dengan adanya sistem penunjang keputusan. Penelitian ini memberikan solusi :

1. Mempercepat penyampaian informasi hasil pertanian secara realtime oleh petani

2. Mempercepat proses pencarian hasil pertanian oleh tengkulak/distributor

3. Optimalisasi pemilihan hasil pertanian berdasarkan lokasi tengkulak/distributor tersebut berada, sehingga ini akan memperpendek jarak dan mengurangi biaya transportasi
\end{abstract}

Penelitian ini merupakan pengembangan dari penelitian sebelumnya yang diusulkan, dimana dalam penelitian sebelumnya juga didanai oleh Hibah PDP tahun 2015 dengan judul Sistem geoserver pertanian Dengan PostGis Guna Mempermudah Pengohasil Data Penyuluhan Petani Di kabupaten Malang berbasis Webgis. Penelitian tersebut masih membangun Website untuk pemetaan lokasi pertanian. Sedang pada usulan penelitian sekarang lebih mengembangkan ke pemanfaatan website tersebut sebagai media komunikasi antara petani dengan tengkulak, serta peningkatan penjualan hasil pertanian dengan memodelkan pemilihan hasil pertanian menggunakan metode WEIGHT PRODUCT Kata kunci: weight product 


\section{PENDAHULUAN}

\subsection{Latar Belakang}

Bidang pertanian berperan penting terhadap perekonomian, khususnya terhadap pendapatan devisa negara di luar minyak dan gas bumi serta dalam perekonomian rakyat tidak bisa diabaikan. Kondisi pertanian yang mempunyai nilai ekonomi yang tinggi dan memiliki pasar yang luas akan mendapat prioritas utama dalam pengembangannya.

Di antara kegunaan dan manfaat yang ada pada bidang pertanian ini tidak lepas oleh sumberdaya yang ada. Sumber daya alam yang ada dapat dimanfaatkan sebaik mungkin dengan cara-cara yang dapat meningkatkan kesejahteraan dan mutu pada setiap individunya. Lain halnya dengan sumber daya manusia yang ada pada bidang pertanian, sebut saja dengan petani dan tengkulak/distributor. Petani sendiri merupakan aktor di bidang pertanian. Yang secara garis besar harus memahami seluk beluk pertanian dan mendata sawah serta hasil pertanian yang ada. Sedangkan tengkulak/distributor merupakan patner petani yang berfungsi menyampaikan/menjualkan hasil pertanian.

Sektor pertanian merupakan sektor yang mempunyai peranan strategis dalam struktur pembangunan perekonomian nasional. Pada dasarnya kegiatan ekonomi merupakan suatu aktivitas atau usaha yang dilakukan manusia dalam bidang ekonomi untuk mewujudkan kemakmuran. Untuk mencapainya, maka kegiatan ekonomi meliputi tiga hal, yaitu produksi, distribusi, dan konsumsi. Kegiatan tersebut antara satu dengan yang lainnya saling berhubungan. Kegiatan distribusi adalah usaha menyalurkan atau menyebarluaskan barang dan jasa dari produsen ke konsumen. Dalam hal ini peranan para distributor sangat penting, karena penghubung antara produsen dengan konsumen, atau antara produsen dengan produsen lainnya. Kegiatan distribusi banyak dipengaruhi oleh permintaan dan penawaran barang dan jasa.

Dan permasahasil yang sering kali tengkulak miliki adalah kesulitannya menemukan lokasi petani yang memiliki hasil panennya cukup baik, baik dari segi kuantitas dan kualitasnya, dan menentukan akan dijual ke mana nantinya. Pemanfaatan Sistem Penunjang Keputusan dapat digunakan untuk membantu para distributor dalam mengambil keputusan dengan cepat, tepat dan lebih baik. Sistem penunjang keputusan sangat tepat jika diterapkan pada permasahasil diatas, dan dapat memberikan alternatif bagi para distributor untuk memperoleh informasi dan keputusan dimana lokasi hasil pertanian yang dibutuhkan berada.

\subsection{Tujuan}

Adapun tujuan dari penelitian yang sedang penulis susun adalah sebagai berikut :

- Guna mempermudah petani memberikan informasi hasil pertanian secara uptodate

- Guna mempercepat proses pencarian hasil pertanian oleh tengkulak/distributor

- Membangun Sistem Penunjang Keputusan guna membantu tengkulak/distributor dalam melakukan pemilihan hasil pertanian berdasarkan lokasi tengkulak/distributor tersebut berada, sehingga ini akan memperpendek jarak dan mengurangi biaya transportasi.

\subsection{Hipotesis}

Hipotesis yang digunakan dalam mengerjakan penelitian ini dapat dijabarkan sebagai berikut bahwa dengan 
pemodelan pemilihan hasil pertanian dengan metode weight product dapat :

- Mempercepat penyampaian informasi hasil pertanian oleh petani

- Mempercepat proses pencarian hasil pertanian oleh tengkulak/distributor

- Optimalisai pemilihan hasil pertanian berdasarkan lokasi tengkulak/distributor tersebut berada, sehingga ini akan memperpendek jarak dan mengurangi biaya transportasi dengan menggunakan sistem penunjang keputusan

\subsection{Ruang Lingkup}

Di penelitian ini dibatasi pembahasanmya sebagai berikut :

a. Memodelkan sistem penunjang keputusan untuk para tengkulak/distributor dalam memlilih hasil pertanian berdasarkan lokasi, jumlah hasil panen, jenis hasil pertanian yang dicari.

b. Metode yang digunakan untuk memodelkan SPK adalah WEIGHT PRODUCT

\subsubsection{Target Uji Coba Perangkat Lunak}

Target uji coba penggunaan perangkat lunak yang akan dibuat adalah :

- Badan Ketahan Pangan dan Pelaksana Penyuluhan(BKP3) kabupaten Malang

- Masyarakat/petani/pemilik hasil pertanian

- Masyarakat/tengkulak/distributor/penj ual hasil pertanian

\subsubsection{Target Luaran Yang InginDicapai} Diharapkan dengan penelitian ini dapat dicapai target luaran sebagai berikut :

- Terciptanya sebuah model SPK untuk pemilihan hasil pertanian dengan metode WEIGHT PRODUCT

- Terbit dalam sebuah jurnal/proceding

\section{TINJAUAN PUSTAKA}

\subsection{Metode Weighted Product}

Metode WP (Weighted Product) merupakan salah satu metode penyelesaian yang ditawarkan untuk menyelesaikan masalah Multi Attribute Decision Making (MADM). Metode WP mirip dengan Metode Weighted Sum (WS), hanya saja metode WP terdapat perkalian dalam perhitungan matematikanya. Metode WP juga disebut analisis berdimensi karena struktur matematikanya menghilangkan satuan ukuran. Metode WP adalah himpunan berhingga dari alternatif keputusan yang dijelaskan dalam beberapa hal kriteria keputusan. Jadi metode ini tidak perlu dinormalisasikan.[4]

Metode perkalian berbobot atau metode WP ini berbeda dengan metode Simple Additive Weighting (SAW) dalam perlakukan awal terhadap hasil penilaian atribut keputusan. Dalam metode WP tidak diperlukan proses normalisasi karena metode ini mengalikan hasil penilaian setiap atribut. Hasil perkalian tersebut belum bermakna sebelum dibandingkan (dibagi) dengan nilai standar. Bobot untuk atribut manfaat berfungsi sebagai pangkat positif dalam proses perkalian antar atribut, sementara bobot berfungsi sebagai pangkat negatif bagi atribut biaya. Tahapan-tahapan perbitungan dalam metode WP adalah sebagai berikut [4][5]:

1. Menentukan alternatif

$$
A=\left\{A_{1}, A_{2}, \ldots . ., A_{i}\right\}
$$

2. Menentukan kriteria yang akan dijadikan acuan dalam pengambilan keputusan

$$
\mathrm{C}=\{\mathrm{C} 1, \mathrm{C} 2, \ldots . ., \mathrm{Cj}\}
$$

3. Menentukan bobot preferensi atau tingkatan kepentingan (W) setiap kriteria.

$$
\mathrm{W}=\{\mathrm{W} 1 \mathrm{~W} 2 \mathrm{~W} 3 \quad \ldots \ldots \ldots \mathrm{Wj}\}
$$

4. Menentukan nilai hasil pemangkatan nilai atribut dengan bobot preferensi 
yang disesuaikan dengan jenis atribut (atribut keuntungan atau setiap atribut biaya), kemudian menentukan hasil penilaian dengan melakukan pengalian untuk setiap nilai atribut (S).

$S_{i}=\prod_{j}^{n}=x_{i j} w j \quad ;$ dengan $\mathrm{i}=1,2, \ldots, \mathrm{m}$

dimana $\Sigma w j=1$. wj adalah pangkat bernilai positif untuk atribut keuntungan, dan bernilai negatif untuk atribut biaya.

5. Nilai preferensi untuk setiap alternatif (Vi) diberikan sebagai :

$$
V_{i}=\frac{\prod_{j}^{n}=1 x_{i j} w j}{\prod_{j}^{n}=1\left(x_{j^{*}}\right)^{w j}} \quad ; \text { dengan } 1=1,2, \ldots, \mathrm{m}
$$

Nilai Vi yang lebih besar mengindikasikan bahwa alternatif $\mathrm{Ai}$ lebih terpilih.

Contoh kasus :

Misalkan nilai setiap alternatif pada setiap atribut diberikan berdasarkan data riil yang ada seperti pada Tabel 2.1, perlu diidentifikasi terlebih dahulu jenis kriterianya, apakah termasuk kriteria keuntungan atau kriteria biaya.

Tabel 2.1 Rating kecocokan dari setiap alternatif pada setiap kriteria

\begin{tabular}{|c|c|c|c|c|c|}
\hline \multirow{2}{*}{$\begin{array}{c}\text { Alter } \\
\text { natif }\end{array}$} & \multicolumn{5}{|c|}{ Kriteria } \\
\cline { 2 - 6 } & $\mathrm{C}_{1}$ & $\mathrm{C}_{2}$ & $\mathrm{C}_{3}$ & $\mathrm{C}_{4}$ & $\mathrm{C}_{5}$ \\
\hline $\mathrm{A}_{1}$ & 0.75 & 2000 & 18 & 50 & 500 \\
\hline $\mathrm{A}_{2}$ & 0.50 & 1500 & 20 & 40 & 450 \\
\hline
\end{tabular}

(Kusumadewi, Hartati, Harjoko, dan Wardoyo, 2006: 78)

Kriteria C2 (kepadatan penduduk di sekitar lokasi) dan C4 (jarak dengan gudang yang sudah ada) adalah criteria keuntungan. Sedangkan kriteria C1 (jarak dengan pasar terdekat), C3 (jarak dari pabrik), dan C5 (harga tanah untuk lokasi) adalah kriteria biaya. Permasahasil kasus di atasakan di selesaikan dengan menggunakan metode Weighted Product
(WP). Sebelumnya akan dilakukan perbaikan bobot terlebih dahulu. Bobot awal $\mathrm{W}=(5,3,4,4,2)$, akan diperbaiki sehingga total bobot $\sum \mathrm{Wj}=1$, dengan cara

$$
\begin{aligned}
& W_{j}=\frac{W_{j}}{\sum W_{j}}: \\
& W_{1}=\frac{5}{5+3+\frac{4}{3}+4+2}=\frac{5}{18}=0,2778 \\
& W_{2}=\frac{3}{5+3+4+4+2}=\frac{4}{18}=0,1667 \\
& W_{3}=\frac{4}{5+3+4+4+2}=\frac{4}{18}=0,2222 \\
& W_{4}=\frac{4}{5+3+4+4+2}=\frac{4}{18}=0,2222 \\
& W_{5}=\frac{2}{5+3+4+4+2}=\frac{2}{18}=0,1111
\end{aligned}
$$

Kemudian vektor $S$ dihitung berdasarkan persamaan $S_{i}=\prod_{j}^{n}=x_{i j}{ }^{w j} ;$ dengan $\mathrm{i}=1$, $2, \ldots, \mathrm{m}$ sebagai berikut :

$S_{I}=\left(0,75^{-0,2778}\right)\left(2000^{0,1667}\right)\left(18^{-0,2222}\right)\left(50^{0,2222}\right)\left(500^{-0,1111}\right)=2,4187$ $S_{2}=\left(0,5^{-0,2778}\right)\left(1500^{0,1667}\right)\left(20^{-0,2222}\right)\left(40^{0,2222}\right)\left(450^{-0,1111}\right)=2,2270$

Nilai vektor yang akan digunakan untuk perankingan dapat dihitung berdasarkan persamaan

$$
\begin{gathered}
V_{i}=\frac{\Pi_{j}^{n}=1 x_{i j^{w j}}}{\Pi_{j}^{n}=1\left(x_{j^{*}}\right)^{w j}} ; \text { dengan } \mathrm{i}=1,2, \ldots, \mathrm{m} \\
V_{1}=\frac{2,4187}{2,4187+2,4270+1,7462}=0,3669 \\
V_{2}=\frac{2,4270}{2,4187+2,4270+1,7462}=0,3682
\end{gathered}
$$

Nilai terbesar ada pada V2 sehingga alternatif A2 adalah alternatif yang terpilih sebagai alternatif terbaik. Dengan kata lain, alternatif A2 akan terpilih sebagai lokasi untuk mendirikan gudang baru. ( Kusumadewi, Hartati, Harjoko, dan Wardoyo, 2006: 79 ). 


\section{PEMODELAN SISTEM}

\subsection{Metode Penelitian}

Dengan mengacu pada perumusan masalah, maka penelitian ini dirancang untuk dilakuan secara berkesinambungan. Yang memiliki tahapan-tahapan ringkas sebagai berikut :

- Melakukan survey dan pengumpulan data hasil pertanian di suatu wilayah, serta letak lokasi distributor.

- Perancangan algoritma dan koding program yang disesuaikan dengan development environtment

- Merancang machine learning (pelatihan data sampel)..

- Penarikan kesimpulan.

\subsection{Pemodelan Berdasarkan Metode Weighted Product}

Proses penilaian hasil berdasarkan metode weighted product digunakan untuk mengetahui langkah-langkah dari proses yang berlangsung pada form proses penilaian. Berikut rancangan proses penilaian hasil berdasarkan metode weighted product.
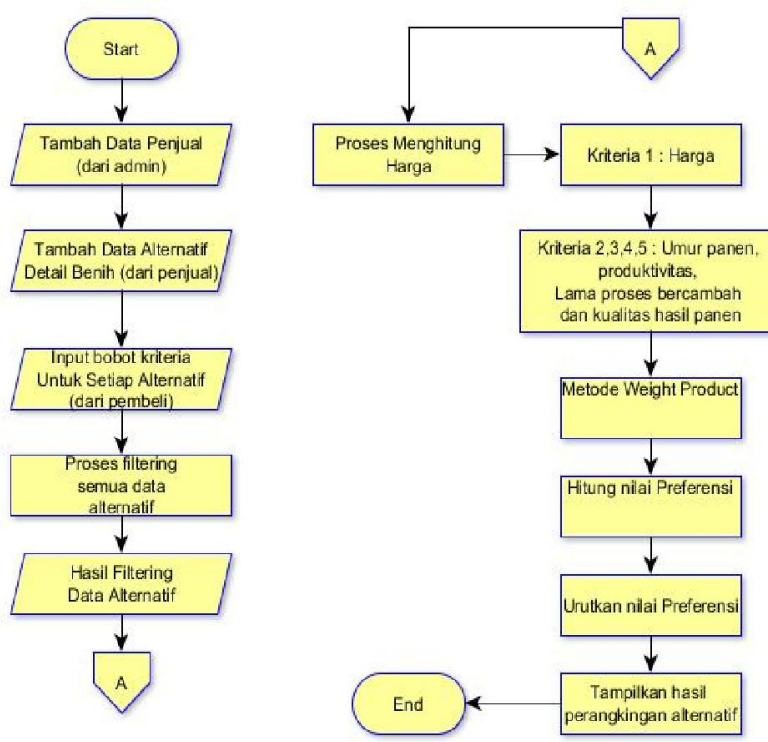

Gambar 3.1 Proses Penilaian Berdasarkan Merode Weighted Product

Keterangan flowchart metode weighted product :
Flowchart pada gambar 3.1 menggambarkan langkah-langkah metode weighted product yang dijalankan pada sistem penunjang keputusan pemilihan hasil. Berikut adalah penjelasan tiap tahap tersebut :

1. Tahap pertama adalah menentukan alternatif-alternatif yang akan digunakan dalam perhitungan. Dalam sistem penunjang keputusan pemilihan hasil ini.

a. Untuk mendapatkan hasil rekomendasi hasil yang bermutu dan sesuai dengan keinginan atau kebutuhan pengguna, maka data alternatif yang digunakan didalam proses perhitungan tidak menggunakan data keseluruhan dari alternatif hasil yang ada. Tetapi penggunaan data alternatif diarahkan atau dikhususkan ke hasil filtering kriteria data alternatif sesuai preferensi pengguna. Sehingga sebelum proses perhitungan metode weighted product dijalankan, proses filtering data alternatif dijalankan terlebih dahulu untuk mendapatkan kumpulan data alternatif yang sesuai dengan kebutuhan pengguna. Selanjutnya menentukan tingkat kepentingan dari setiap kriteria, dan didapat bobot preferensi $W=(10,8)$, setelah didapat bobot preferensi, dilakukan penilaian sebagai berikut:

Tabel 3.1 Data alternative

\begin{tabular}{|c|c|c|}
\hline Alternatif & Harga & Produktivitas \\
\hline$H 1$ & 549 & 120 \\
\hline$H 2$ & 449 & 70 \\
\hline$H 3$ & 349 & 100 \\
\hline
\end{tabular}

2. Tahap kedua adalah menentukan kriteria keuntungan atau kriteria biaya, kriteria produktivitas dan kualitas hasil produksi adalah kriteria keuntungan 
3. Tahap ketiga adalah melakukan perbaikan bobot terlebih dahulu, seperti yang sudah diketahui sebelumnya, bobot preferensi yang ada yaitu :

$\mathrm{W}=(10,8)$

Dari bobot tersebut dilakukan perbaikan bobot seperti berikut :

Tabel 3.2 Perbaikan Bobot

\begin{tabular}{|c|c|}
\hline Harga & Produktivitas \\
\hline 0.4 & 0.1 \\
\hline
\end{tabular}

4. Tahap keempat adalah Menentukan nilai hasil pemangkatan nilai atribut dengan bobot preferensi yang disesuaikan dengan jenis atribut (atribut keuntungan atau setiap atribut biaya), kemudian menentukan hasil penilaian dengan melakukan pengalian untuk setiap nilai atribut (S).

a. Dalam kasus pemilihan hasil ini, beberapa kriteria yang termasuk atribut keuntungan diantaranya produktivitas. Sedangkan kriteria yang masuk dalam atribut biaya yaitu harga, umur panen, lama proses kecambah.

b. Formula yang digunakan dalam perhitungan ini adalah

$$
\begin{gathered}
S_{i}=\prod_{j}^{n}=x_{i j w j} \quad ; \text { dengan } \mathrm{i}=1,2, \ldots, \mathrm{m} \\
\text { dimana } \Sigma w \mathrm{j}=1 .
\end{gathered}
$$

Dan wj adalah pangkat bernilai positif untuk atribut keuntungan, dan bernilai negatif untuk atribut biaya.

$$
\begin{aligned}
& \mathrm{S}=\left(C 1^{-W 1}\right) \cdot\left(C 2^{-W 2}\right) \\
& \mathrm{S} 1=\left(549^{-0.56}\right) \cdot\left(80^{-0.44}\right) . \\
& \quad=0.021150758 \\
& \mathrm{~S} 2 \quad=\left(449^{-0.56}\right) \cdot\left(60^{-0.44}\right) . \\
& \quad=0.02295833 \\
& \text { S3 }=\left(349^{-0.56}\right) \cdot\left(120^{-0.44}\right) . \\
& \quad=0.022043432
\end{aligned}
$$

Tabel 3.3 Data hasil vektor S

\begin{tabular}{|l|l|}
\hline Alternatif & Vektor S \\
\hline H1 & 0.021150758 \\
\hline
\end{tabular}

\begin{tabular}{|l|l|}
\hline H2 & 0.02295833 \\
\hline H3 & 0.022043432 \\
\hline
\end{tabular}

4. Tahap kelima adalah menetukan nilai preferensi untuk setiap alternatif (Vi) diberikan sebagai berikut :

$$
V_{i}=\frac{\prod_{j}^{n}=1 x_{i j} w j}{\prod_{j}^{n}=1\left(x_{j^{*}}\right)^{w j}} \quad ; \text { dengan } 1=1,2, \ldots, \mathrm{m}
$$

Tabel 3.4 Data hasil preferensi

\begin{tabular}{|l|l|}
\hline \multicolumn{1}{|c|}{ Alternatif } & \multicolumn{1}{c|}{ Vektor V } \\
\hline H1 & 0.319727176 \\
\hline H2 & 0.347051476 \\
\hline H3 & 0.333221348 \\
\hline
\end{tabular}

6. Tahap keenam adalah melakukan perangkingan atau pengurutan berdasarkan nilai preferensi (Vi) yang dihasilkan. Nilai Vi yang lebih besar mengindikasikan bahwa alternatif $\mathrm{Hi}$ lebih terpilih. Berdasarkan tabel 3.10 data hasil preferensi diatas, maka alternatif $\mathrm{H} 2$ dengan nilai preferensi 0.347051476 .

\section{PENGEMBANGAN SISTEM}

\subsection{Pengembangan Lanjutan}

Sistem Webgis yang saat ini dimiliki oleh pemerintahan kabupaten Malang dalam bidang pertanian ini masih mencakup informasi peta secara keseluruhan. karena untuk pengohasil data pada peta daerah tertentu membutuhkan waktu dan pengambilan data secara real dalam waktu bertahap sehingga pemerintah kabupaten khususnya pada bidang Badan Ketahan Pangan dan Pelaksana Penyuluhan Kabupaten Malang kesulitan untuk mendata dan mengolah laporan data yang ada. Selain itu informasi ketersediaan pangan pada tiap daerah pun sulit untuk didata dan di informasikan secara bertahap sehingga ketahanan pangan pada tiap daerah pun terhambat karena informasi yang lambat dan tidak secara berkala. Ada beberapa webgis yang 
menjadi tempat informasi untuk mendapatkan beberapa info mengenai bidang pertanian ini, seperti webgis kementrian pertanian yaitu http://gis.deptan.go.id/. Tetapi infomasi didalamnya terbatas dan tidak terfokus pada daerah-daerah yang ada.

Dengan melihat dan mengamati webgis yang ada pada pemerintah kabupaten Malang di bidang pertanian ini, diperoleh gambaran dari sistem webgis tersebut informasi yang ada dan ditampilkan sedikit. Sehingga petani yang ingin menyampaikan hasil ketersediaan pangan secara real kesulitan. Berikutnya belum termanfaatkannya webgis tersebut sebagai media promosi/marketing bagi petani untuk menjual hasil pertaniannya.

Karena para petani atau distirutor yang mengusulkan pemanfaatan lebih webgis tersebut, maka dibutuhkan sistem informasi terutama webgis yang lebih berguna dan efisien karena cepat dalam pengohasil data dan dibutuhkan oleh petani serta distributor yang menggunakan webgis sebagai salah satu media komunikasi antara penjual pembeli. Dan webgis ini memiliki fungsi yang sama pula terhadap ketahanan pangan yang ada pada daerah tertentu. Dengan webgis mengenai pertanian ini diharapkan informasi tentang ketersediaan pangan yang ada pada daerah curungrejo atau sekitarnya dapat menjadi tolak ukur ketahanan pangan pada daerah tersebut. Karena informasi akan di olah dan di informasikan melalui webgis sehingga informasi mengenai hasil dan ketersediaan pangan tersebut dapat digunakan semaksimal mungkin.

Gambaran sistem secara umum tercermin dalam Arsitektur Webgis Pertanian untuk Pengohasil data seperti di bawah ini,

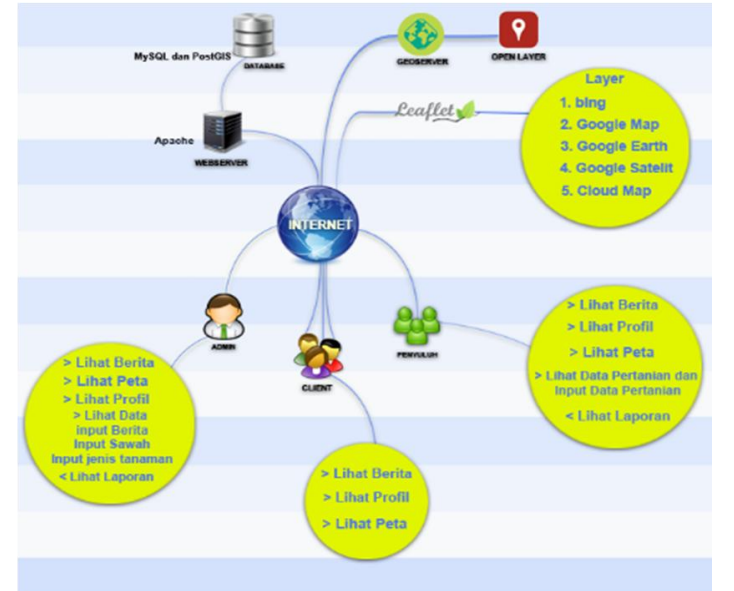

Gambar 4.1 Arsitektur WEBGIS

Pertanian untuk pengohasil data petani

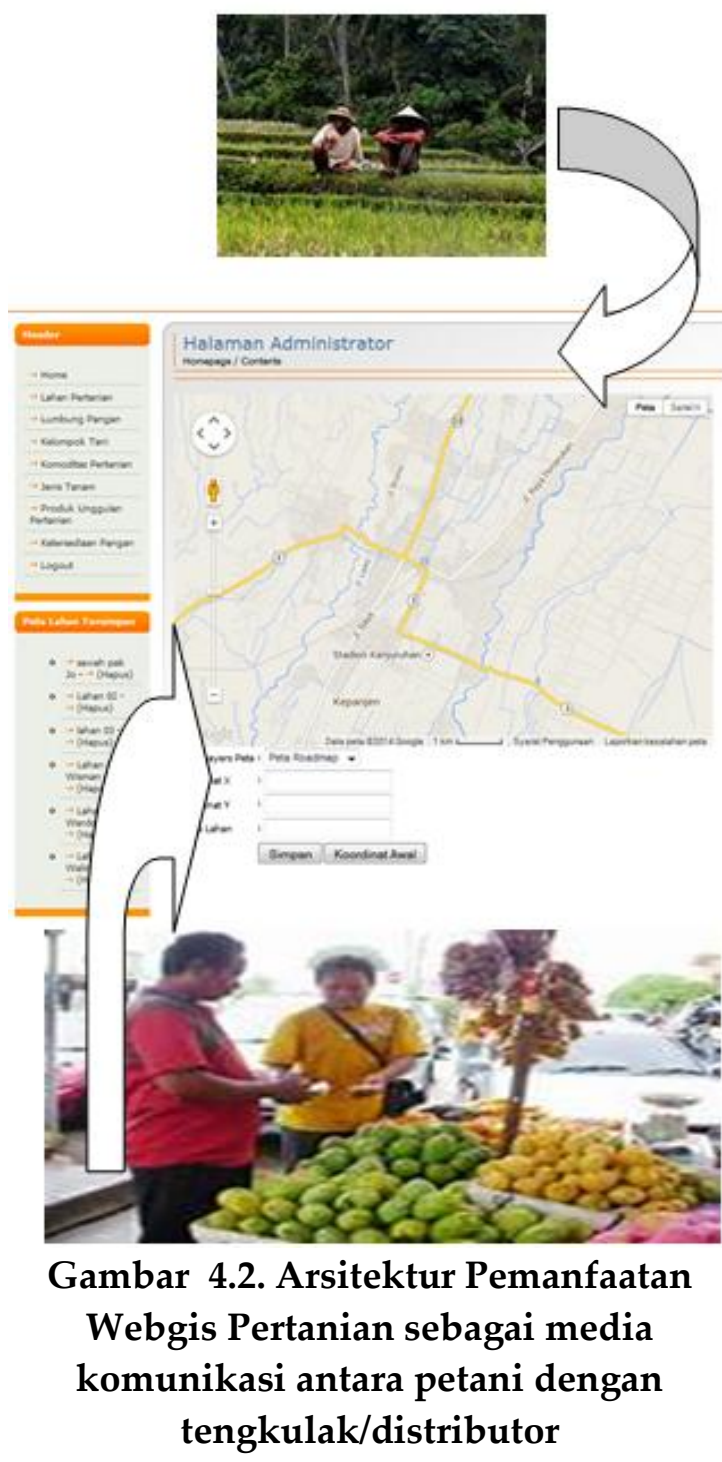

Dari permasahasil di atas mengakibatkan komunikasi antara petani dengan distributor kurang cepat serta distributor 
tidak memiliki informasi yang lengkap sehingga distributor kurang optimal dalam mengambil/membeli hasil panen petani. Di mana nantinya akan menggunakan sistem informasi webgis yang dapat menampung semua informasiinformasi dan mengolah data terkait hasil pertanian para petani yang di pantau oleh penyuluh petanian. Di dalam sistem informasi webgis yang baru,diharapkan sistem ini dapat membantu dan berfungsi maksimal bagi distributor.

Sistem Informasi Geografis Pertanian berbasis web merupakan sistem informasi yang dapat menyelesaikan masalah yang dihadapi Pemerintah Kabupaten Malang di bidang pertanian ini, karena webgis mudah untuk diakses, maka pihak BKP3,dapat memperoleh serta memberikan informasi yang cepat. Sehingga dapat meningkatkan kinerja masing-masing personal.

\section{KESIMPULAN DAN SARAN \\ Kesimpulan}

1. Metode Weight Produt dalam diterapkan dalam aplikasi WEBGIS untuk menunjang keputusan.

2. Pemodelan ini sebagai pijakan dalam pengembangan sistem WEBGIS agar lebih berguna bagi masyarakat.

\section{Saran}

Pemodelan ini dapat diimplementasikan dalam bentuk aplikasi, sehingga aplikasi tersebut dapat bermanfaat bagi masyarakat.

\section{DAFTAR PUSTAKA}

[1] Muh Aziz, Slamet Pujiono, 2012, Sistem Informasi Geografis Berbasis Desktop dan Web, Yogyakarta.

[2] HorwardBuler, Chritopher Schmid, Dane Springmeyer and josh Livni, Spasial Refernce, Online (http://apstialreference.orfg)
[3] Pahlevi, Muhamad Reza, 2013, Sumber-sumber data spasial untuk pengembangan SIG.Online (http://ejhapahlevi.blogspot.com/ 2013/05sumber-sumber-dataspasial-untuk.html) diakses kamis 10 April 2014

[4] Turban, Efraim.(2005).Decision Support System and Intelligent System. ANDI Yogyakarta : Yogyakarta

[5] Prahasta, Eddy.(2004).Sistem Informasi Geografis. Informatika : Bandung

[6] http://distanbun.malangkab.go.id/ konten-16.html/

Kamis 29 januari 2015 pukul 18.00

[7] Budi Gunawan,2011. Pemanfaatan Sistem Informasi Geografis untuk Analisis Potensi Sumber Daya Hasil Pertanian. Jurnal Sains dan Teknologi, Vol 4 No 2, Desember 2011.

[8] Kasumahadi, dkk, 2013. Analisis Spasial Sumber Daya Alam Perkebunan Karet Rakyat Kota Banjarmasin Dengan Menggunakan Data Penginderaan Jauh. Jurnal Enviro Scienteae, Vol 9, 2013, 156-164

[9] Kristoko, dkk, 2013.Perancangan Sistem Informasi Geografis Sebaran Tanaman Pangan Berbasis Spasial dan Multitier Menggunakan server, Jurnal Informatika Vol 9 No 2, Oktober 2013

[10] Zed Nahdi, dkk, 2014. Implementasi Sistem Informasi Geografis Untuk Inventarisasi Data Komoditas Pertanian dan informasi Kondisi Hasil di Kabupaten Kudus, Jurnal Ilmu Pertanian, vol 23 No 1, 2014, 4656 